medRxiv preprint doi: https://doi.org/10.1101/2020.04.13.20064006; this version posted July 22, 2020. The copyright holder for this preprint

(which was not certified by peer review) is the author/funder, who has granted medRxiv a license to display the preprint in perpetuity.

All rights reserved. No reuse allowed without permission.

\title{
Epigenetic profiling of Italian patients identified methylation sites associated with hereditary Transthyretin amyloidosis
}

Antonella De Lillo, ${ }^{1}$ Gita A. Pathak, ${ }^{2,3}$ Flavio De Angelis, ${ }^{1,2,3}$ Marco Di Girolamo, ${ }^{4}$ Marco Luigetti, ${ }^{5,6}$

Mario Sabatelli, ${ }^{6,7}$ Federico Perfetto, ${ }^{8}$ Sabrina Frusconi, ${ }^{9}$ Dario Manfellotto, ${ }^{4}$ Maria Fuciarelli, ${ }^{1}$ Renato

Polimanti $^{2,3 *}$

${ }^{1}$ Department of Biology, University of Rome Tor Vergata, Rome, Italy

${ }^{2}$ Department of Psychiatry, Yale University School of Medicine, West Haven, CT, USA

${ }^{3}$ VA CT Healthcare Center, West Haven, CT, USA

${ }^{4}$ Clinical Pathophysiology Center, Fatebenefratelli Foundation -'San Giovanni Calibita’ Fatebenefratelli

Hospital, Rome, Italy

${ }^{5}$ Fondazione Policlinico Universitario A. Gemelli IRCCS, UOC Neurologia, Rome, Italy

${ }^{6}$ Università Cattolica del Sacro Cuore, Rome, Italy

${ }^{7}$ 'Centro Clinico NEMO adulti’, Rome, Italy

${ }^{8}$ Regional Amyloid Centre, Azienda Ospedaliero-Universitaria Careggi, Florence, Italy

${ }^{9}$ Genetic Diagnostics Unit, Laboratory Department, Careggi University Hospital, Florence, Italy

*Corresponding author:

Dr. Renato Polimanti. Department of Psychiatry, Yale University School of Medicine and VA CT

Healthcare Center, VA CT 116A2, 950 Campbell Avenue, West Haven,

CT 06516, USA. Tel: +1 2039325711 x5745; Fax: +1 203 937-3897; E-mail:

renato.polimanti@yale.edu; ORCID: 0000-0003-0745-6046 
medRxiv preprint doi: https://doi.org/10.1101/2020.04.13.20064006; this version posted July 22, 2020. The copyright holder for this preprint (which was not certified by peer review) is the author/funder, who has granted medRxiv a license to display the preprint in perpetuity.

All rights reserved. No reuse allowed without permission.

\begin{abstract}
Hereditary Transthyretin (TTR) Amyloidosis (hATTR) is a rare life-threatening disorder caused by amyloidogenic coding mutations located in $T T R$ gene. To understand the high phenotypic variability observed among carriers of TTR disease-causing mutations, we conducted an epigenome-wide association study (EWAS) assessing more than 700,000 methylation sites and testing epigenetic difference of $T T R$ coding mutation carriers vs. non-carriers, We observed a significant methylation change at $\operatorname{cg} 09097335$ site located in Beta-secretase 2 (BACE2) gene (beta $\left.=-0.60, \mathrm{p}=6.26 \times 10^{-8}\right)$. This gene is involved in a protein interaction network enriched for biological processes and molecular pathways related to amyloidbeta metabolism (Gene Ontology:0050435, q=0.007), amyloid fiber formation (Reactome HSA-977225, $\mathrm{q}=0.008$ ), and Alzheimer's disease (KEGG hsa05010, $\mathrm{q}=2.2 \times 10^{-4}$ ). Additionally, TTR and BACE2 share APP (Amyloid-beta precursor protein) as a validated protein interactor. Within TTR gene region, we observed that Val30Met disrupts a methylation site, cg13139646, causing a drastic hypomethylation in carriers of this amyloidogenic mutation (beta=-2.18, $\mathrm{p}=3.34 \times 10^{-11}$ ). Cg13139646 showed co-methylation with cg19203115 $\left(r^{2}=0.32\right)$, which showed significant epigenetic differences between symptomatic and asymptomatic carriers of amyloidogenic mutations (beta $=-0.56, \mathrm{p}=8.6 \times 10^{-4}$ ). In conclusion, we provide novel insights related to the molecular mechanisms involved in the complex heterogeneity of hATTR, highlighting the role of epigenetic regulation in this rare disorder.
\end{abstract}

\title{
Key words
}

hATTR, amyloidosis, Val30Met mutation, epigenetics, methylation, modifier gene. 
medRxiv preprint doi: https://doi.org/10.1101/2020.04.13.20064006; this version posted July 22, 2020. The copyright holder for this preprint (which was not certified by peer review) is the author/funder, who has granted medRxiv a license to display the preprint in perpetuity.

All rights reserved. No reuse allowed without permission.

\section{Background}

Hereditary transthyretin amyloidosis (hATTR; OMIM\#105210) is a life-threatening disorder caused by transthyretin (TTR) misfolding and consequently amyloid fibril deposition in several tissues (e.g., peripheral nerves, heart, and gastrointestinal tract) $(1,2)$. This rare condition is characterized by extreme clinical heterogeneity including age of onset, penetrance, and clinical display (3-5). To date, more than 130 amyloidogenic mutations have been identified in the coding regions of the TTR gene, which are the cause of hATTR (6). The prevalence of hATTR is estimated to be approximately 1/100,000 (7). However, endemic areas of hATTR were identified in Portugal and Sweden $(4,5)$. Although both of these regions are affected by the same amyloidogenic mutation, Val30Met (rs28933979), the penetrance and age of onset are different: early age of onset and high penetrance in Portugal $(4,5,8,9)$ vs. late age of onset and low penetrance in Sweden and in non-endemic countries $(3,10,11)$. It has been hypothesized that hATTR phenotypic heterogeneity is due to the contribution of genetic and non-genetic factors involved in the complex genotype-phenotype correlation observed (12-18). Recent data strongly support the role of non-coding regulatory variation on $T T R$ gene expression, as one of the mechanisms affecting the phenotypic manifestations observed in carriers of TTR amyloidogenic mutations (19-22). Among genomic regulatory features, epigenetic modifications are demonstrated to be key mechanisms in modulating a wide range of molecular functions and potential targets to develop novel treatments (23-25). Of several epigenetic modifications, DNA methylation is the most studied with respect to human traits and diseases (23). With respect to monogenic disorders, methylation studies investigate the role of epigenetic changes involved in the phenotypic expression observed among carriers of disease-causing mutations (26-28). While epigenetic modifications have the potential to be involved in hATTR pathogenic mechanisms, to our knowledge no study has explored methylation changes of patients affected by this life-threatening disease. In the present study, we conducted an epigenome-wide association study (EWAS) to identify DNA methylation sites associated with hATTR, investigating 48 carriers of $T T R$ amyloidogenic mutations and 32 controls. We also tested whether there are significant epigenetic changes among carriers of different amyloidogenic mutations. The results obtained showed: i) hATTR confirmed 
medRxiv preprint doi: https://doi.org/10.1101/2020.04.13.20064006; this version posted July 22, 2020. The copyright holder for this preprint (which was not certified by peer review) is the author/funder, who has granted medRxiv a license to display the preprint in perpetuity.

All rights reserved. No reuse allowed without permission.

cases have significant methylation changes in modifier genes potentially involved in amyloidogenic processes; ii) carriers of Val30Met mutation showed a significant hypomethylation in TTR gene when compared to the carriers of other TTR amyloidogenic mutations.

\section{Results}

The epigenome-wide analysis testing the differences between 48 carriers of TTR amyloidogenic mutations and 32 controls identified a significant methylation site surviving false discovery rate multiple testing correction (FDR q<0.05) at the cg09097335 site located in Beta-secretase 2 (BACE2) gene body (beta $=-0.60, p=6.26 \times 10^{-8}$, FDR $\left.\mathrm{q}=0.044\right)$. Carriers of $T T R$ amyloidogenic mutations showed a significant hypomethylation when compared to controls (Figure 1). To understand whether methylation at this $\mathrm{CpG}$ site is associated with disease-associated genetic differences or post-disease processes, we compared hATTR patients, asymptomatic carriers of TTR mutations, and controls. Significant differences were observed for i) hATTR patients vs. controls (beta $=-0.402, p=5.7 \times 10^{-4}$ ) and ii) asymptomatic carriers vs. controls (beta=-0.716, $p=3.21 \times 10^{-5}$ ), but no difference was present between hATTR patients vs. asymptomatic carriers (beta $=0.137, p=0.332$ ). Leveraging GTEx data (29), we observed a complementary transcriptomic regulation between $T T R$ and $B A C E 2$ genes where the first is mainly expressed in its source organ (i.e. liver) while the second is expressed in target organs of TTR amyloid deposits (Figure 2). We investigated interactive proteins related to $T T R$ and BACE2 loci based on multiple experimental and computational evidence, identifying five candidates with medium-to-highest interaction confidence (Figure 2B). These include FYN (FYN proto-oncogene, Src family tyrosine kinase; interaction score=0.809), BACE1 (Beta-secretase 1; interaction score=0.804), APP (amyloid-beta precursor protein; interaction score=0.430), IGHV3-11 (immunoglobulin heavy variable 3-11; interaction score=0.412), and ENSG00000259680 (uncharacterized protein similar to an immunoglobulin heavy variable 3/OR16 gene; interaction score=0.412). Among them, TTR showed the highest interaction with APP protein (interaction score $=0.936$ ). BACE2 protein interactive network (Figure 3) showed functional enrichments for several biological processes and molecular pathways (Table 1). Among the enrichments directly related to BACE2 function that survived false discovery rate (FDR) multiple testing correction, we observed: 
medRxiv preprint doi: https://doi.org/10.1101/2020.04.13.20064006; this version posted July 22, 2020. The copyright holder for this preprint (which was not certified by peer review) is the author/funder, who has granted medRxiv a license to display the preprint in perpetuity. All rights reserved. No reuse allowed without permission.

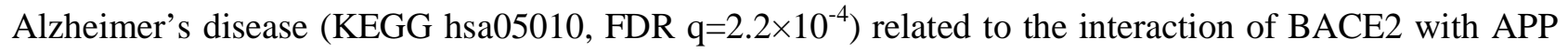
and BACE1; membrane protein ectodomain proteolysis (GO:0006509, FDR q=0.007) and amyloid-beta metabolic process (GO:0050435, FDR q=0.007) related to BACE2-BACE1 interaction; protein metabolic process (GO:0019538, FDR q=0.043) related to the interaction of BACE with APP, BACE1, FYN, and IGHV3-11. The interactions of other proteins within BACE2 interactive network also highlighted amyloid-related functional enrichments: amyloid fiber formation (Reactome HSA-977225, FDR q=0.008) and response to amyloid-beta (GO:1904645, FDR q=0.009) related to the interaction of APP with BACE1 and FYN, respectively.

Within TTR gene region, we observed that Val30Met mutation disrupts a methylation site, cg13139646, causing a drastic hypomethylation in Val30Met carriers when compared with carriers of other TTR mutations (beta $=-2.18, \mathrm{p}=3.34 \times 10^{-11}$ ). To understand whether the disruption of $\operatorname{cg} 13139646$ may have functional implications related to hATTR pathogenesis, we performed a co-methylation analysis with respect to cg13139646. We identified 34 methylation sites that are correlated with $\operatorname{cg} 13139646$ site $\left(\mathrm{r}^{2}>\right.$ 0.20; Additional File 1). Considering these co-methylated $\mathrm{CpG}$ sites, we investigated epigenetic differences among hATTR patients, asymptomatic carriers of TTR mutations, and controls (Additional File 2). Applying a Bonferroni correction accounting for the number of $\mathrm{CpG}$ sites tested, we observed a significant methylation difference between hATTR patients and asymptomatic carriers of TTR amyloidogenic mutations at $\operatorname{cg} 19203115\left(\mathrm{r}^{2}=0.317\right.$, beta $\left.=-0.555, \mathrm{p}=8.6 \times 10^{-4}\right)$. Nominally significant methylation differences were observed i) between carriers vs. non-carriers at $\operatorname{cg} 11481443\left(\mathrm{r}^{2}=0.263\right.$, beta $\left.=-0.306, p=3.4 \times 10^{-3}\right)$ and $\operatorname{cg} 02936398\left(\mathrm{r}^{2}=0.256\right.$, beta=0.177, $\left.\mathrm{p}=4.9 \times 10^{-2}\right)$; ii) hATTR patients and asymptomatic carriers at $\operatorname{cg} 14311811\left(\mathrm{r}^{2}=0.261\right.$, beta $\left.=-0.273, \mathrm{p}=3.8 \times 10^{-2}\right)$. Considering symptoms reported by hATTR patients, we identified CpG sites co-methylated with cg13139646 (i.e., the site disrupted by Val30Met mutation) nominally associated with cardiac involvement $\left(\operatorname{cg} 27392998, \mathrm{r}^{2}=0.444\right.$, beta $=-0.235, \mathrm{p}=7.5 \times 10^{-3} ; \quad \operatorname{cg} 18038361, \mathrm{r}^{2}=0.433$, beta $\left.=0.227, \mathrm{p}=5 \times 10^{-2}\right)$, carpal tunnel syndrome (cg16492377; $\mathrm{r}^{2}=0.347, \quad$ beta $\left.=-0.229, \mathrm{p}=1.8 \times 10^{-2}\right)$, and peripheral nervous system involvement (cg14719951, $\mathrm{r}^{2}=0.268$, beta=0.249, $\mathrm{p}=3.5 \times 10^{-2}$ ). Since some of these $\mathrm{CpG}$ sites were mapped to loci located near TTR gene (Additional File 2), we analyzed TTR transcriptomic profile in hATTR target 
medRxiv preprint doi: https://doi.org/10.1101/2020.04.13.20064006; this version posted July 22, 2020. The copyright holder for this preprint (which was not certified by peer review) is the author/funder, who has granted medRxiv a license to display the preprint in perpetuity.

All rights reserved. No reuse allowed without permission.

organs, observing a different pattern when compared to the expression of the surrounding genes (Additional File 3).

\section{Discussion}

hATTR is a rare multi-organ disorder caused by TTR misfolding and consequently amyloid deposition in several tissues (30). This life-threatening condition is characterized by high clinical heterogeneity with respect to age of onset, penetrance, and phenotypic manifestation (1-10, 30). Although TTR amyloidogenic mutations are the cause of TTR misfolding, non-coding variation and modifier genes are hypothesized to be involved in wide variability of phenotypic manifestations observed in carriers of $T T R$ disease-causing mutations $(12,15,17-22)$. Epigenetic modifications (e.g., DNA methylation changes) could also play an important role in the molecular network regulating the hATTR amyloidogenic process (25). To explore this hypothesis, we conducted an EWAS investigating more than 700,000 methylation sites in 48 carriers of TTR amyloidogenic mutations and 32 non-carriers. A CpG site (cg09097335) located in BACE2 gene was significantly hypomethylated in carriers when compared to non-carriers. This gene encodes Beta-secretase 2, a protein mainly known for its role in cleaving APP protein in amyloidbeta, which is a key factor involved in AD pathogenesis (31-33). Several studies have shown that, unlike BACE1 which serves as the primary $\beta$-secretase protein cleaving APP to amyloid-beta, BACE2 is poorly expressed in the brain and its cleaving ability increases following an inflammatory response (34). APP processing occurs via three proteolytic cleavages caused by $\alpha$ - $\beta$ - and $\gamma$-secretase (35). In nonamyloidogenic processes, $\alpha$ - and $\gamma$-secretases lead to the production of a smaller P3 fragment and APP intracellular domain, while, in the amyloidogenic pathway, $\beta$-secretase and $\gamma$-secretase produce amyloidbeta (35-39). Our results also showed a high-confidence interaction between APP and TTR. Numerous studies explored the interactions between these two amyloidogenic proteins, displaying a relevant biological role of TTR in amyloid-beta aggregation and clearance in AD patients (40-44). Specifically, TTR instability reduces the clearance of amyloid-beta, increasing amyloid toxicity in the brain (40-42). Metal ions and interaction with other proteins could also affect TTR stability (40). Interestingly, a significant association between amyloid-beta levels and $\mathrm{AD}$ was identified in $\mathrm{AD}$ patients with TTR 
medRxiv preprint doi: https://doi.org/10.1101/2020.04.13.20064006; this version posted July 22, 2020. The copyright holder for this preprint (which was not certified by peer review) is the author/funder, who has granted medRxiv a license to display the preprint in perpetuity.

All rights reserved. No reuse allowed without permission.

Val30Met $(40,44)$. A putative amyloidogenic role of amyloid-beta in hATTR was also identified in a post-mortem analysis of a Val30Met carrier where both TTR and amyloid-beta were deposited in the cerebral leptomeningeal and cortical blood vessel walls with a part of the vessel wall occupied by a combination of TTR and amyloid-beta aberrant proteins (43). These previous findings strongly indicate an interplay between the pathogenic mechanisms involved in hATTR and AD. Our epigenome-wide study identified BACE2 as a potential key factor in this interaction. As previously discussed, BACE2 protein plays a minor role in APP cleaving in the brain $(33,34)$, while its activity increases in peripheral tissues under inflammatory response (34). Our transcriptomic analysis showed that BACE2 is expressed in tissues affected by TTR amyloid deposits (i.e., heart, nerves, colon, small intestine, and adipose tissues). Accordingly, the methylation change observed in the TTR-mutation carriers is possibly due to the role of BACE2 in response to the inflammation induced by TTR amyloidogenic process in peripheral tissues (45).

Within TTR gene region, we observed that Val30Met disrupts a CpG site, causing a drastic hypomethylation in the carriers of this mutation. SNPs at CpG sites disrupting the methylation reactions can be associated with changes in regulatory function. $(46,47)$. To explore the functional consequences of cg13139646 disruption, we analyzed the co-methylation of this site with CpG sites in the surrounding regions (NC_000018.9: 28,171,000-30,171,500). Indeed, co-methylation patterns reflect specific molecular mechanisms responsible for the regulation of multiple genes located in the same region (48). In our analysis, some of the CpG sites identified map to TTR gene region, while others map in nearby loci. Considering hATTR target organs, these surrounding loci with co-methylated CpG sites have higher gene expression than TTR. We speculate that these genes may be involved in the formation of TTR amyloid deposits. This hypothesis is supported by the fact that co-methylated $\mathrm{CpG}$ sites are associated with hATTR traits. The strongest evidence was observed with respect to cg19203115 mapped in B4GALT6 gene. Considering a Bonferroni correction accounting for the number of co-methylated CpG sites tested, cg19203115 showed a significant difference in methylation levels between hATTR patients and asymptomatic carriers of TTR mutations. B4GALT6 gene encodes Beta-1,4-Galactosyltransferase 6, a type II membrane-bound glycoprotein that has exclusive specificity for the donor substrate UDP- 
medRxiv preprint doi: https://doi.org/10.1101/2020.04.13.20064006; this version posted July 22, 2020. The copyright holder for this preprint (which was not certified by peer review) is the author/funder, who has granted medRxiv a license to display the preprint in perpetuity.

All rights reserved. No reuse allowed without permission.

galactose. The enzyme activity of B4GALT6 changes in response to inflammatory processes (49). B4GALT6 stimulates astrocyte activation through the catalyzation of lactosylceramide synthesis, which in turn controls the production of pro-inflammatory cytokines and chemokines (49). Hence, observing methylation changes in B4GALT6 may be associated with inflammatory response to TTR amyloid deposits. Nominally significant differences were observed for $\mathrm{CpG}$ sites mapped in other surrounding loci: DSC2 (cg02936398, Carriers vs. Controls); DSG2 (cg14311811, hATTR patients vs. asymptomatic carriers); DSC3 (cg16492377, carpal tunnel syndrome in hATTR patients). DSC2 and DSG2 encode components of the desmosome. This protein complex is specialized for cell-to-cell adhesion in myocardial tissue and mutations in $D S C 2$ and $D S G 2$ genes are associated with arrhythmogenic right ventricular cardiomyopathy (50). In an in vivo study of myocardial inflammation, DSC2 overexpression was observed to lead to tissue necrosis, fibrosis, and calcification of ventricles (51). This process alters homeostasis among desmosomal proteins, inducing a cascade of different cell-cell interactions leading to cardiac remodeling (51). In hATTR, cardiac amyloid fibril depositions also led to tissue dysfunctions (7). Heart failure, restrictive cardiomyopathy, and rhythm disturbances (i.e. conduction system diseases, atrial fibrillation, and ventricular tachycardia) are the main clinical signs that occur after the accumulation of misfolded TTR protein (52-54). Furthermore, transcriptomic interaction is observed between TTR and DSG2 to induce hypertrophic cardiomyopathy in animal models (55). In this context, methylation changes in DSC2 and DSG2 genes could reflect pathogenic processes in hATTR target organs. We also identified two CpG sites co-methylated with cg13139646 (i.e., the methylation site disrupted by Val30Met mutation) that are nominally associated with hATTR symptoms. Cg18038361 is located in TTR gene promoter region and is associated with cardiac involvement in hATTR patients. DNA methylation changes in promoter regions are well-known to play an important role in gene expression regulation $(56,57)$. Cg18038361 association may be linked to regulatory changes in TTR gene expression. Lastly, two CpG sites - cg16492377 and cg14719951, map to DSC3 transcription start site and gene body, respectively. In our analysis, methylation changes in these sites were associated with carpal tunnel syndrome and peripheral nervous system involvement in hATTR patients, respectively. DSC3 gene encodes the desmocollin-3 a calcium-dependent glycoprotein. Low DSC3 expression in 
medRxiv preprint doi: https://doi.org/10.1101/2020.04.13.20064006; this version posted July 22, 2020. The copyright holder for this preprint (which was not certified by peer review) is the author/funder, who has granted medRxiv a license to display the preprint in perpetuity.

All rights reserved. No reuse allowed without permission.

human epidermis leads to a loss of tissue integrity (58). We speculate that cg16492377 methylation association with carpal tunnel syndrome may be related to changes in DSC3 transcriptomic regulation.

Although we provide novel findings regarding the role of methylation changes in hATTR, our study presents several limitations. Since hATTR is a rare disease, we investigated a relatively small sample size. Our calculation showed that the sample size investigated in our main analysis should provide $>80 \%$ statistical power to detect medium effect sizes $\left(\Delta_{\beta}=0.2\right.$; Additional File 4). However, large samples will be needed to investigate how epigenetic changes affect hATTR symptoms and differences across $T T R$ amyloidogenic mutations. Our cohort showed age and sex differences between carriers of TTR amyloidogenic mutations and controls. Our analysis was adjusted for these confounding variables together with blood cell types, genetic principal components, and epigenetically-determined smoking status. More balanced case-control groups are needed to investigate how epigenetic differences are associated differently between sexes and across age groups. We used transcriptomic data from GTEx project to explore the potential mechanisms related to the epigenetic associations identified. Further studies generating transcriptomic and epigenomic information across multiple informative tissues will provide a more comprehensive understanding of the molecular processes involved in hATTR. The CpG site disrupted by Val30Met mutation (i.e., cg13139646) is co-methylated with CpG sites associated with hATTR and its symptoms. We speculated possible regulatory mechanisms, also discussing the potential role of TTR-surrounding genes as hATTR modifier loci. These findings should be considered preliminary results that need to be replicated and expanded by future investigations.

\section{Conclusions}

Our study provided novel insights regarding the pathogenesis of hATTR, supporting the involvement of methylation changes in the amyloidogenic process induced by TTR disease-causing mutations. Further studies will be needed to characterize specific mechanisms underlying the epigenetic associations, in particular, the potential role of amyloid-beta metabolic process and inflammatory response. The understanding of how methylation changes modulate the penetrance and the severity of TTR mutations could lead to the identification of novel targets to develop treatments and screening tools for the carriers. 
medRxiv preprint doi: https://doi.org/10.1101/2020.04.13.20064006; this version posted July 22, 2020. The copyright holder for this preprint (which was not certified by peer review) is the author/funder, who has granted medRxiv a license to display the preprint in perpetuity.

All rights reserved. No reuse allowed without permission.

\section{Methods}

Thirty-eight symptomatic patients and 10 asymptomatic TTR mutations carriers were recruited from three Italian centers for the treatment of systemic amyloidosis: "San Giovanni Calibita" Fatebenefratelli Hospital, Isola Tiberina - Rome, Fondazione Policlinico Universitario “A. Gemelli” - Rome and Careggi University Hospital - Florence (16-20). Thirty-two controls were recruited by the Department of Biology - University of Rome "Tor Vergata" (Table 3). hATTR diagnosis was based on the presence of clinical signs and symptoms and the presence of an amyloidogenic mutation on TTR gene. The coding mutations identified include: Val30Met (rs28933979), Phe64Leu (rs121918091), Ile68Leu (rs121918085), Ala120Ser (rs876658108), and Val122Ile (rs76992529). One hATTR patient is a carrier of a mutation (rs36204272) in an intronic region with a putative clinical impact (59). Carpal tunnel syndrome and cardiac involvement with confirmed TTR amyloid deposits are present in rs36204272 carrier. Information regarding the organ involvements was collected for each patient: peripheral and nerve involvement (nerve conduction study); cardiac involvement (electrocardiographic and echocardiography anomalies); gastrointestinal involvement (gastric paresis, stypsis, or diarrhea); autonomic neurological involvement (orthostatic hypotension and urinary incontinence); ocular involvement (vitreous opacities): and carpal tunnel syndrome (median nerve decompression) (11, 60-62). The present study was approved under the protocol 39/18 by the Comitato Etico Indipendente, Fondazione Policlinico Tor Vergata - Rome, Italy.

\section{DNA methylation analysis}

DNA was extracted using the phenol/chloroform protocol (63) and purified through Amicon Ultra-0.5 mL Centrifugal Filters (EMD Millipore) to achieve a DNA concentration of $100 \mathrm{ng} / \mu \mathrm{L}$. DNA concentration was checked via NanoDrop technology (ND-1000, Thermofisher Scientific) and Qubit Quantitation technology (High Accuracy \& Sensitivity, Thermofisher). DNA methylation analysis was executed in two phases: the EZ DNA Methylation kit (Zymo Research) was used to perform sodium bisulfite conversion; the Illumina Infinium Methylation EPIC Chip (with over 850,000 methylation sites; Illumina Inc.) was 
medRxiv preprint doi: https://doi.org/10.1101/2020.04.13.20064006; this version posted July 22, 2020. The copyright holder for this preprint (which was not certified by peer review) is the author/funder, who has granted medRxiv a license to display the preprint in perpetuity.

All rights reserved. No reuse allowed without permission.

used to quantify DNA methylation according to the standard Illumina protocol. The methylation array analysis was performed at the Connecting bio-research and Industry Center, Trieste - Italy.

\section{Preprocessing, quality control, and normalization}

The raw signal intensity files were processed and cleaned using R 3.6 with ChAMP package (64). The ratio of methylated and unmethylated intensities from idat files was converted into beta values for further processing. The probes failing thresholds on detection value, bead count, sites near SNPs, probes that align to multiple positions, sex chromosomes and outliers were removed. None of the samples failed quality control. The remaining 718,509 probes for 80 individuals were normalized with BMIQ. Batch effects were assessed using singular vector decomposition and corrected with ComBat method (65). The genomic lambda of the case-control association was 1.03, calculated using QQPerm package (https://cran.r-project.org/web/packages/QQperm/index.html).

\section{Blood cell type composition, genetic variability estimation, and smoking prediction}

References-based method was employed to adjust for the heterogeneity due to the cell type composition of the whole blood samples investigated (66). This method uses specific DNA methylation signatures derived from purified whole blood cell-type as biomarkers of cell identity, to correct beta value dataset. Cell proportions for five cell-types (B cells, granulocytes, monocytes, natural killer cells, and T cells) were detected, and a linear regression was applied $(64,66)$. To account for the genetic variability among the samples investigated, principal components (PCs) were calculate using the method proposed by Barfield, Almli (67). This approach allowed us to compute PCs based on CpGs selected for their proximity to SNPs. The data obtained can be used to adjust for population stratification in DNA methylation studies when genome-wide SNP data are unavailable (67). Cigarette smoke has a very large effect on DNA methylation profile, triggering alteration at multiple CpGs (68). Consequently, smoking status needs to be considered as a potential confounder in epigenetic association studies. EpiSmokEr 
medRxiv preprint doi: https://doi.org/10.1101/2020.04.13.20064006; this version posted July 22, 2020. The copyright holder for this preprint (which was not certified by peer review) is the author/funder, who has granted medRxiv a license to display the preprint in perpetuity.

All rights reserved. No reuse allowed without permission.

package was used to classify the smoking status of each participant on the basis of their epigenetic profile (69). Briefly, EpiSmoker is a prediction tool that provides smoking probabilities for each individual (never-smoker, former-smoker, and current smoker) using a set of 121 informative CpG sites (68).

\section{Data analysis}

We conducted two epigenome-wide analyses testing 718,509 methylation sites. First, we investigated the methylation changes between 48 carriers of a TTR amyloidogenic mutation) and 32 controls (i.e., noncarriers). Considering $\mathrm{CpG}$ sites that survive epigenome-wide multiple testing correction, we also verified whether the associations observed were due to disease-associated genetic differences or post-disease processes, comparing i) patients affected by hATTR vs. controls, ii) asymptomatic carriers of TTR mutations $v s$. controls, and iii) patients affected by hATTR $v s$. asymptomatic carriers of TTR mutations.

To investigate the functionality of the $\mathrm{CpG}$ disrupted by Val30Met mutation, we analyzed its comethylation with CpG sites in the surrounding region (NC_000018.9: 28,171,000-30,171,500). This region was selected based on the TTR regulatory mechanisms observed in previous studies (20-22). We used $\operatorname{cor}() \mathrm{R}$ function to calculate Pearson's correlation coefficient testing 367 sites and considering the methylation levels ( $\mathrm{M}$ values) in the controls. $\mathrm{CpG}$ sites with high co-methylation $\left(\mathrm{r}^{2}>0.2\right)$ were investigated with respect to hATTR-related traits (i.e., carrier status, disease status, and symptoms). In all association analyses, we implemented a linear regression analysis including cell composition proportions, top three genetic PCs, epigenetically-determined smoking status, age, and sex as covariates. FDR method (70) was applied to adjust the results for epigenome-wide testing and the q-value $<0.05$ was considered as the significance threshold. Co-expression analysis was conducted using GTEx v8 (29) via the Multi Gene Query available at https://www.gtexportal.org/. Ggplot2 R package (71) was employed to plot comethylation pattern results. STRING v.11.0 (72) was used to identify protein interaction with the loci identified, considering experiments, co-expression, co-occurrence, gene fusion, and neighborhood as active sources and an interaction score higher than 0.4 (medium confidence). The protein interaction network was investigated further conducting functional enrichments association related to the proteinprotein interactions identified considering Gene Ontologies (73) for biological processes and molecular pathways available from Reactome Database (74) and Kyoto Encyclopedia of Genes and Genomes 
medRxiv preprint doi: https://doi.org/10.1101/2020.04.13.20064006; this version posted July 22, 2020. The copyright holder for this preprint (which was not certified by peer review) is the author/funder, who has granted medRxiv a license to display the preprint in perpetuity.

All rights reserved. No reuse allowed without permission.

(KEGG) (75). FDR (q-value < 0.05) was applied to account for multiple testing assuming the whole genome as the statistical background. Statistical power calculation was done using pwrEWAS tool (76) considering medium and small effect sizes $\left(\Delta_{\beta}=0.5\right.$ and 0.2 , respectively) and multiple sample sizes.

\section{List of abbreviations}

AD, Alzheimer disease; APP, amyloid beta precursor protein; hATTR, Hereditary transthyretin amyloidosis; BACE1, beta-secretase 1; B4GALT6, beta-1,4-Galactosyltransferase 6; BACE2, betasecretase 2; DSC2, descmocollin-2; DSC3, desmocollin-3; DSG3, desmoglein-3 EWAS, epigenomewide association studies; FDR, false discovery rate; FYN, FYN proto-oncogene, Src family tyrosine kinase; IGHV3-11, immunoglobulin heavy variable 3-11; TTR, transthyretin.

\section{Declarations}

\section{Ethics approval and consent to participate}

This study was approved under the protocol 39/18 by the Comitato Etico Indipendente, Fondazione Policlinico Tor Vergata - Rome, Italy. Informed consent was obtained from each participant involved.

\section{Availability of data and materials}

Data supporting the findings of this study are available within this article and its additional files.

\section{Competing interests}

Drs. Fuciarelli and Polimanti received research grants from Pfizer Inc. to conduct epigenetic studies of hATTR. The other authors reported no biomedical financial interests or potential conflicts of interest.

\section{Funding}


medRxiv preprint doi: https://doi.org/10.1101/2020.04.13.20064006; this version posted July 22, 2020. The copyright holder for this preprint (which was not certified by peer review) is the author/funder, who has granted medRxiv a license to display the preprint in perpetuity.

All rights reserved. No reuse allowed without permission.

This study was supported by an Investigator-Initiated Research from Pfizer Inc. to the University of Rome Tor Vergata. Pfizer Inc. had no role in the study design, data analysis, and results interpretation of the present study.

\section{Authors' contributions}

ADL, FDA, MF, and RP were involved in study design. MDG, ML, MS, FP, SF, and DM conducted the recruitment and assessment of the participants. ADL, GAP, and RP carried out the statistical analysis. All authors were involved in the interpretation of the results. ADL and RP wrote the first draft of the manuscript and all authors contributed to the final version of the manuscript.

\section{Acknowledgements}

We thank the participants involved in this study and their caregivers.

\section{Bibliography}

1. Palaninathan SK. Nearly 200 X-ray crystal structures of transthyretin: what do they tell us about this protein and the design of drugs for TTR amyloidoses? Curr Med Chem. 2012;19(15):2324-42.

2. Ueda M, Ando Y. Recent advances in transthyretin amyloidosis therapy. Transl Neurodegener. 2014;3:19.

3. Hellman U, Alarcon F, Lundgren HE, Suhr OB, Bonaiti-Pellie C, Plante-Bordeneuve V. Heterogeneity of penetrance in familial amyloid polyneuropathy, ATTR Val30Met, in the Swedish population. Amyloid. 2008;15(3):181-6.

4. Conceicao I. Clinical features of TTR-FAP in Portugal. Amyloid. 2012;19 Suppl 1:71-2.

5. Parman Y, Adams D, Obici L, Galan L, Guergueltcheva V, Suhr OB, et al. Sixty years of transthyretin familial amyloid polyneuropathy (TTR-FAP) in Europe: where are we now? A European network approach to defining the epidemiology and management patterns for TTR-FAP. Curr Opin Neurol. 2016;29 Suppl 1:S3-S13. 
medRxiv preprint doi: https://doi.org/10.1101/2020.04.13.20064006; this version posted July 22, 2020. The copyright holder for this preprint (which was not certified by peer review) is the author/funder, who has granted medRxiv a license to display the preprint in perpetuity.

All rights reserved. No reuse allowed without permission.

6. Conceicao I, Damy T, Romero M, Galan L, Attarian S, Luigetti M, et al. Early diagnosis of ATTR amyloidosis through targeted follow-up of identified carriers of TTR gene mutations. Amyloid. 2019;26(1):3-9.

7. Ando Y, Coelho T, Berk JL, Cruz MW, Ericzon BG, Ikeda S, et al. Guideline of transthyretinrelated hereditary amyloidosis for clinicians. Orphanet J Rare Dis. 2013;8:31.

8. Sousa A, Coelho T, Barros J, Sequeiros J. Genetic epidemiology of familial amyloidotic polyneuropathy (FAP)-type I in Povoa do Varzim and Vila do Conde (north of Portugal). Am J Med Genet. 1995;60(6):512-21.

9. Plante-Bordeneuve V, Carayol J, Ferreira A, Adams D, Clerget-Darpoux F, Misrahi M, et al. Genetic study of transthyretin amyloid neuropathies: carrier risks among French and Portuguese families. J Med Genet. 2003;40(11):e120.

10. Sousa A, Andersson R, Drugge U, Holmgren G, Sandgren O. Familial amyloidotic polyneuropathy in Sweden: geographical distribution, age of onset, and prevalence. Hum Hered. $1993 ; 43(5): 288-94$.

11. Luigetti M, Conte A, Del Grande A, Bisogni G, Madia F, Lo Monaco M, et al. TTR-related amyloid neuropathy: clinical, electrophysiological and pathological findings in 15 unrelated patients. Neurol Sci. 2013;34(7):1057-63.

12. Alves-Ferreira M, Coelho T, Santos D, Sequeiros J, Alonso I, Sousa A, et al. A Trans-acting Factor May Modify Age at Onset in Familial Amyloid Polyneuropathy ATTRV30M in Portugal. Mol Neurobiol. 2018;55(5):3676-83.

13. Bonaiti B, Olsson M, Hellman U, Suhr O, Bonaiti-Pellie C, Plante-Bordeneuve V. TTR familial amyloid polyneuropathy: does a mitochondrial polymorphism entirely explain the parent-of-origin difference in penetrance? Eur J Hum Genet. 2010;18(8):948-52.

14. Santos D, Coelho T, Alves-Ferreira M, Sequeiros J, Mendonca D, Alonso I, et al. Variants in RBP4 and AR genes modulate age at onset in familial amyloid polyneuropathy (FAP ATTRV30M). Eur J Hum Genet. 2016;24(5):756-60. 
medRxiv preprint doi: https://doi.org/10.1101/2020.04.13.20064006; this version posted July 22, 2020. The copyright holder for this preprint (which was not certified by peer review) is the author/funder, who has granted medRxiv a license to display the preprint in perpetuity.

All rights reserved. No reuse allowed without permission.

15. Soares ML, Coelho T, Sousa A, Batalov S, Conceicao I, Sales-Luis ML, et al. Susceptibility and modifier genes in Portuguese transthyretin V30M amyloid polyneuropathy: complexity in a single-gene disease. Hum Mol Genet. 2005;14(4):543-53.

16. Iorio A, De Angelis F, Di Girolamo M, Luigetti M, Pradotto L, Mauro A, et al. Most recent common ancestor of TTR Val30Met mutation in Italian population and its potential role in genotypephenotype correlation. Amyloid. 2015;22(2):73-8.

17. Polimanti R, Di Girolamo M, Manfellotto D, Fuciarelli M. Functional variation of the transthyretin gene among human populations and its correlation with amyloidosis phenotypes. Amyloid. 2013;20(4):256-62.

18. Polimanti R, Di Girolamo M, Manfellotto D, Fuciarelli M. In silico analysis of TTR gene (coding and non-coding regions, and interactive network) and its implications in transthyretin-related amyloidosis. Amyloid. 2014;21(3):154-62.

19. Iorio A, De Angelis F, Di Girolamo M, Luigetti M, Pradotto LG, Mazzeo A, et al. Population diversity of the genetically determined TTR expression in human tissues and its implications in TTR amyloidosis. BMC Genomics. 2017;18(1):254.

20. Iorio A, De Lillo A, De Angelis F, Di Girolamo M, Luigetti M, Sabatelli M, et al. Non-coding variants contribute to the clinical heterogeneity of TTR amyloidosis. Eur J Hum Genet. 2017;25(9):105560.

21. De Lillo A, De Angelis F, Di Girolamo M, Luigetti M, Frusconi S, Manfellotto D, et al. Phenomewide association study of TTR and RBP4 genes in 361,194 individuals reveals novel insights in the genetics of hereditary and wildtype transthyretin amyloidoses. Hum Genet. 2019;138(11-12):1331-40.

22. Polimanti R, Nunez YZ, Gelernter J. Increased Risk of Multiple Outpatient Surgeries in AfricanAmerican Carriers of Transthyretin Val122Ile Mutation Is Modulated by Non-Coding Variants. J Clin Med. 2019;8(2).

23. Feinberg AP. The Key Role of Epigenetics in Human Disease Prevention and Mitigation. N Engl J Med. 2018;378(14):1323-34. 
medRxiv preprint doi: https://doi.org/10.1101/2020.04.13.20064006; this version posted July 22, 2020. The copyright holder for this preprint (which was not certified by peer review) is the author/funder, who has granted medRxiv a license to display the preprint in perpetuity.

All rights reserved. No reuse allowed without permission.

24. Yan H, Tian S, Slager SL, Sun Z, Ordog T. Genome-Wide Epigenetic Studies in Human Disease: A Primer on -Omic Technologies. Am J Epidemiol. 2016;183(2):96-109.

25. Szymczak S, Dose J, Torres GG, Heinsen FA, Venkatesh G, Datlinger P, et al. DNA methylation QTL analysis identifies new regulators of human longevity. Hum Mol Genet. 2020.

26. Clissold RL, Ashfield B, Burrage J, Hannon E, Bingham C, Mill J, et al. Genome-wide methylomic analysis in individuals with HNF1B intragenic mutation and 17q12 microdeletion. Clin Epigenetics. 2018;10(1):97.

27. Guay SP, Brisson D, Munger J, Lamarche B, Gaudet D, Bouchard L. ABCA1 gene promoter DNA methylation is associated with HDL particle profile and coronary artery disease in familial hypercholesterolemia. Epigenetics. 2012;7(5):464-72.

28. Magalhaes M, Rivals I, Claustres M, Varilh J, Thomasset M, Bergougnoux A, et al. DNA methylation at modifier genes of lung disease severity is altered in cystic fibrosis. Clin Epigenetics. 2017;9:19.

29. Aguet F, Barbeira AN, Bonazzola R, Brown A, Castel SE, Jo B, et al. The GTEx Consortium atlas of genetic regulatory effects across human tissues. bioRxiv. 2019:787903.

30. Luigetti M, Romano A, Di Paolantonio A, Bisogni G, Sabatelli M. Diagnosis and Treatment of Hereditary Transthyretin Amyloidosis (hATTR) Polyneuropathy: Current Perspectives on Improving Patient Care. Ther Clin Risk Manag. 2020;16:109-23.

31. Zheng H, Koo EH. Biology and pathophysiology of the amyloid precursor protein. Mol Neurodegener. 2011;6(1):27.

32. Sassi C, Ridge PG, Nalls MA, Gibbs R, Ding J, Lupton MK, et al. Influence of Coding Variability in APP-Abeta Metabolism Genes in Sporadic Alzheimer's Disease. PLoS One. 2016;11(6):e0150079.

33. Wang Z, Xu Q, Cai F, Liu X, Wu Y, Song W. BACE2, a conditional beta-secretase, contributes to Alzheimer's disease pathogenesis. JCI Insight. 2019;4(1).

34. Voytyuk I, Mueller SA, Herber J, Snellinx A, Moechars D, van Loo G, et al. BACE2 distribution in major brain cell types and identification of novel substrates. Life Sci Alliance. 2018;1(1):e201800026. 
medRxiv preprint doi: https://doi.org/10.1101/2020.04.13.20064006; this version posted July 22, 2020. The copyright holder for this preprint (which was not certified by peer review) is the author/funder, who has granted medRxiv a license to display the preprint in perpetuity.

All rights reserved. No reuse allowed without permission.

35. Zhang YW, Thompson R, Zhang H, Xu H. APP processing in Alzheimer's disease. Mol Brain. 2011;4:3.

36. Hartl D, May P, Gu W, Mayhaus M, Pichler S, Spaniol C, et al. A rare loss-of-function variant of ADAM17 is associated with late-onset familial Alzheimer disease. Mol Psychiatry. 2020;25(3):629-39.

37. Suh J, Choi SH, Romano DM, Gannon MA, Lesinski AN, Kim DY, et al. ADAM10 missense mutations potentiate beta-amyloid accumulation by impairing prodomain chaperone function. Neuron. 2013;80(2):385-401.

38. Tambini MD, Norris KA, D'Adamio L. Opposite changes in APP processing and human Abeta levels in rats carrying either a protective or a pathogenic APP mutation. Elife. 2020;9.

39. Durrant CS, Ruscher K, Sheppard O, Coleman MP, Ozen I. Beta secretase 1-dependent amyloid precursor protein processing promotes excessive vascular sprouting through NOTCH3 signalling. Cell Death Dis. 2020;11(2):98.

40. Alemi M, Silva SC, Santana I, Cardoso I. Transthyretin stability is critical in assisting beta amyloid clearance- Relevance of transthyretin stabilization in Alzheimer's disease. CNS Neurosci Ther. 2017;23(7):605-19.

41. Costa R, Goncalves A, Saraiva MJ, Cardoso I. Transthyretin binding to A-Beta peptide--impact on A-Beta fibrillogenesis and toxicity. FEBS Lett. 2008;582(6):936-42.

42. Du J, Murphy RM. Characterization of the interaction of beta-amyloid with transthyretin monomers and tetramers. Biochemistry. 2010;49(38):8276-89.

43. Sakai K, Asakawa M, Takahashi R, Ishida C, Nakamura R, Hamaguchi T, et al. Coexistence of transthyretin- and Abeta-type cerebral amyloid angiopathy in a patient with hereditary transthyretin V30M amyloidosis. J Neurol Sci. 2017;381:144-6.

44. Xiang Q, Bi R, Xu M, Zhang DF, Tan L, Zhang C, et al. Rare Genetic Variants of the Transthyretin Gene Are Associated with Alzheimer's Disease in Han Chinese. Mol Neurobiol. 2017;54(7):5192-200. 
medRxiv preprint doi: https://doi.org/10.1101/2020.04.13.20064006; this version posted July 22, 2020. The copyright holder for this preprint (which was not certified by peer review) is the author/funder, who has granted medRxiv a license to display the preprint in perpetuity.

All rights reserved. No reuse allowed without permission.

45. Azevedo EP, Guimaraes-Costa AB, Bandeira-Melo C, Chimelli L, Waddington-Cruz M, Saraiva EM, et al. Inflammatory profiling of patients with familial amyloid polyneuropathy. BMC Neurol. 2019;19(1):146.

46. Gertz J, Varley KE, Reddy TE, Bowling KM, Pauli F, Parker SL, et al. Analysis of DNA methylation in a three-generation family reveals widespread genetic influence on epigenetic regulation. PLoS Genet. 2011;7(8):e1002228.

47. Hellman A, Chess A. Extensive sequence-influenced DNA methylation polymorphism in the human genome. Epigenetics Chromatin. 2010;3(1):11.

48. Affinito O, Palumbo D, Fierro A, Cuomo M, De Riso G, Monticelli A, et al. Nucleotide distance influences co-methylation between nearby CpG sites. Genomics. 2020;112(1):144-50.

49. Mayo L, Trauger SA, Blain M, Nadeau M, Patel B, Alvarez JI, et al. Regulation of astrocyte activation by glycolipids drives chronic CNS inflammation. Nat Med. 2014;20(10):1147-56.

50. Ohno S. The genetic background of arrhythmogenic right ventricular cardiomyopathy. J Arrhythm. 2016;32(5):398-403.

51. Brodehl A, Belke DD, Garnett L, Martens K, Abdelfatah N, Rodriguez M, et al. Transgenic mice overexpressing desmocollin-2 (DSC2) develop cardiomyopathy associated with myocardial inflammation and fibrotic remodeling. PLoS One. 2017;12(3):e0174019.

52. Cheung CC, Roston TM, Andrade JG, Bennett MT, Davis MK. Arrhythmias in Cardiac Amyloidosis: Challenges in Risk Stratification and Treatment. Can J Cardiol. 2020;36(3):416-23.

53. Macedo AVS, Schwartzmann PV, de Gusmao BM, Melo MDT, Coelho-Filho OR. Advances in the Treatment of Cardiac Amyloidosis. Curr Treat Options Oncol. 2020;21(5):36.

54. Henein MY, Suhr OB, Arvidsson S, Pilebro B, Westermark P, Hornsten R, et al. Reduced left atrial myocardial deformation irrespective of cavity size: a potential cause for atrial arrhythmia in hereditary transthyretin amyloidosis. Amyloid. 2018;25(1):46-53.

55. Prestes PR, Marques FZ, Lopez-Campos G, Lewandowski P, Delbridge LMD, Charchar FJ, et al. Involvement of human monogenic cardiomyopathy genes in experimental polygenic cardiac hypertrophy. Physiol Genomics. 2018;50(9):680-7. 
medRxiv preprint doi: https://doi.org/10.1101/2020.04.13.20064006; this version posted July 22, 2020. The copyright holder for this preprint (which was not certified by peer review) is the author/funder, who has granted medRxiv a license to display the preprint in perpetuity.

All rights reserved. No reuse allowed without permission.

56. Jjingo D, Conley AB, Yi SV, Lunyak VV, Jordan IK. On the presence and role of human genebody DNA methylation. Oncotarget. 2012;3(4):462-74.

57. Meng H, Cao Y, Qin J, Song X, Zhang Q, Shi Y, et al. DNA methylation, its mediators and genome integrity. Int J Biol Sci. 2015;11(5):604-17.

58. Ayub M, Basit S, Jelani M, Ur Rehman F, Iqbal M, Yasinzai M, et al. A homozygous nonsense mutation in the human desmocollin-3 (DSC3) gene underlies hereditary hypotrichosis and recurrent skin vesicles. Am J Hum Genet. 2009;85(4):515-20.

59. Levine TD, Bland RJ. Incidence of nonamyloidogenic mutations in the transthyretin gene in patients with autonomic and small fiber neuropathy. Muscle Nerve. 2018;57(1):140-2.

60. Russo M, Mazzeo A, Stancanelli C, Di Leo R, Gentile L, Di Bella G, et al. Transthyretin-related familial amyloidotic polyneuropathy: description of a cohort of patients with Leu64 mutation and late onset. J Peripher Nerv Syst. 2012;17(4):385-90.

61. Mazzeo A, Russo M, Di Bella G, Minutoli F, Stancanelli C, Gentile L, et al. Transthyretin-Related Familial Amyloid Polyneuropathy (TTR-FAP): A Single-Center Experience in Sicily, an Italian Endemic Area. J Neuromuscul Dis. 2015;2(s2):S39-S48.

62. Gagliardi C, Perfetto F, Lorenzini M, Ferlini A, Salvi F, Milandri A, et al. Phenotypic profile of Ile68Leu transthyretin amyloidosis: an underdiagnosed cause of heart failure. Eur J Heart Fail. 2018;20(10):1417-25.

63. Budowle B, Moretti, T., Smith, J., and Dizinno, J. DNA typing protocols: Molecular Biology and Forensic analysis. A Bio Techniques® Books Publications (Natick, MA: Eaton Publishing). 2000.

64. Tian Y, Morris TJ, Webster AP, Yang Z, Beck S, Feber A, et al. ChAMP: updated methylation analysis pipeline for Illumina BeadChips. Bioinformatics. 2017;33(24):3982-4.

65. Johnson WE, Li C, Rabinovic A. Adjusting batch effects in microarray expression data using empirical Bayes methods. Biostatistics. 2007;8(1):118-27.

66. Houseman EA, Accomando WP, Koestler DC, Christensen BC, Marsit CJ, Nelson HH, et al. DNA methylation arrays as surrogate measures of cell mixture distribution. BMC Bioinformatics. 2012;13:86. 
medRxiv preprint doi: https://doi.org/10.1101/2020.04.13.20064006; this version posted July 22, 2020. The copyright holder for this preprint (which was not certified by peer review) is the author/funder, who has granted medRxiv a license to display the preprint in perpetuity.

All rights reserved. No reuse allowed without permission.

67. Barfield RT, Almli LM, Kilaru V, Smith AK, Mercer KB, Duncan R, et al. Accounting for population stratification in DNA methylation studies. Genet Epidemiol. 2014;38(3):231-41.

68. Zeilinger S, Kuhnel B, Klopp N, Baurecht H, Kleinschmidt A, Gieger C, et al. Tobacco smoking leads to extensive genome-wide changes in DNA methylation. PLoS One. 2013;8(5):e63812.

69. Bollepalli S, Korhonen T, Kaprio J, Anders S, Ollikainen M. EpiSmokEr: a robust classifier to determine smoking status from DNA methylation data. Epigenomics. 2019;11(13):1469-86.

70. Benjamini Y, Hochberg, Y. Controlling the False Discovery Rate: A Practical and Powerful Approach to Multiple Testing. Journal of the Royal Statistical Society Series B (Methodological). 1995;57:289-300.

71. Wickham H. ggplot2: Elegant Graphics for Data Analysis. springer-Verlag New York. 2016.

72. Szklarczyk D, Gable AL, Lyon D, Junge A, Wyder S, Huerta-Cepas J, et al. STRING v11: protein-protein association networks with increased coverage, supporting functional discovery in genomewide experimental datasets. Nucleic Acids Res. 2019;47(D1):D607-D13.

73. The Gene Ontology C. The Gene Ontology Resource: 20 years and still GOing strong. Nucleic Acids Res. 2019;47(D1):D330-D8.

74. Jassal B, Matthews L, Viteri G, Gong C, Lorente P, Fabregat A, et al. The reactome pathway knowledgebase. Nucleic Acids Res. 2020;48(D1):D498-D503.

75. Kanehisa M, Furumichi M, Tanabe M, Sato Y, Morishima K. KEGG: new perspectives on genomes, pathways, diseases and drugs. Nucleic Acids Res. 2017;45(D1):D353-D61.

76. Graw S, Henn R, Thompson JA, Koestler DC. pwrEWAS: a user-friendly tool for comprehensive power estimation for epigenome wide association studies (EWAS). BMC Bioinformatics. 2019;20(1):218. 
medRxiv preprint doi: https://doi.org/10.1101/2020.04.13.20064006; this version posted July 22, 2020. The copyright holder for this preprint (which was not certified by peer review) is the author/funder, who has granted medRxiv a license to display the preprint in perpetuity. All rights reserved. No reuse allowed without permission.

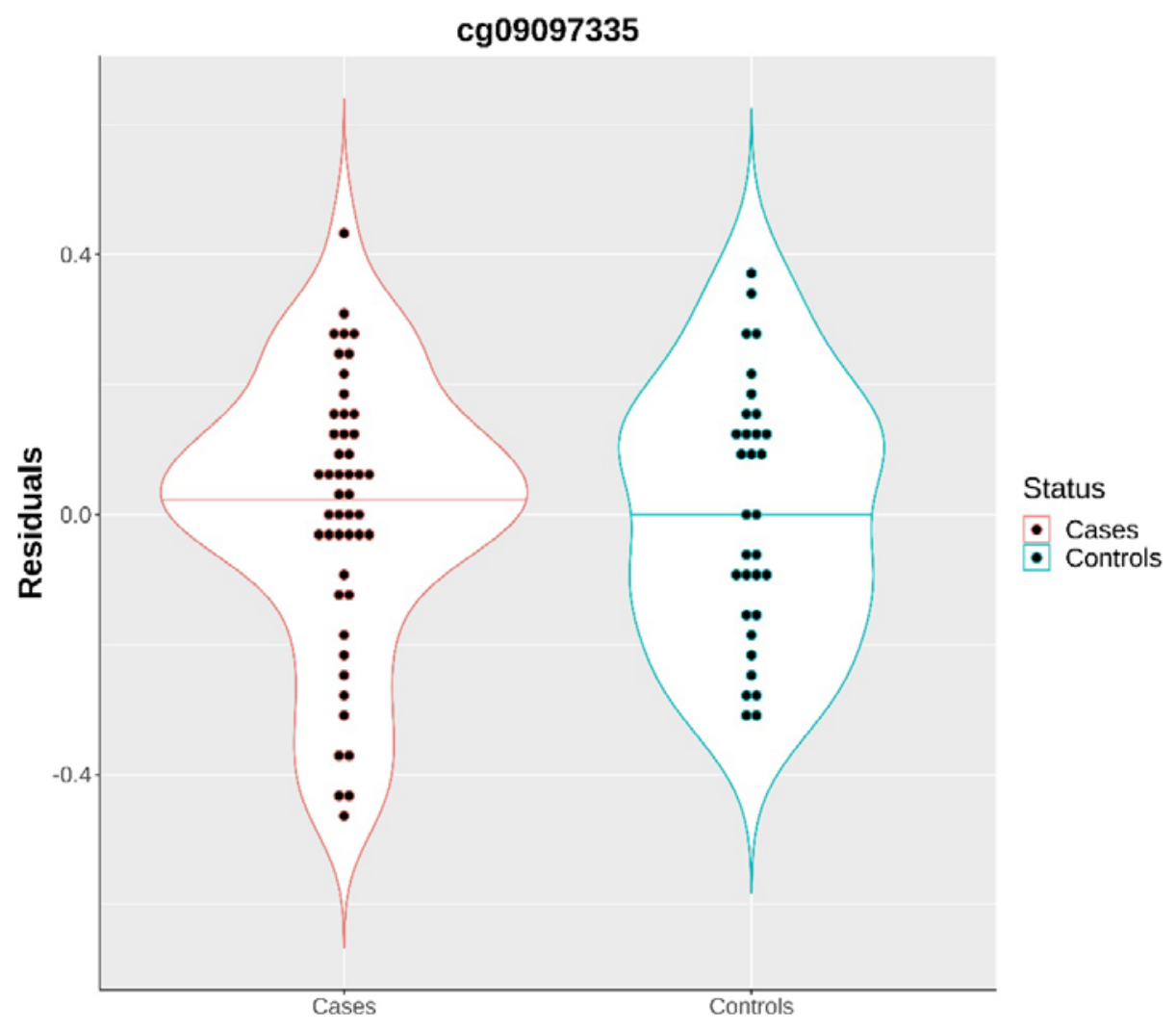

Figure 1: Methylation levels of $\operatorname{cg} 09097335$ site in carriers (cases) vs. non-carriers (controls) of amyloidogenic mutations. The residuals were obtained adjusting $\mathrm{M}$ values for age, sex, cell composition proportions, top three genetic principal components, and epigenetically-determined smoking status. 
medRxiv preprint doi: https://doi.org/10.1101/2020.04.13.20064006; this version posted July 22, 2020. The copyright holder for this preprint (which was not certified by peer review) is the author/funder, who has granted medRxiv a license to display the preprint in perpetuity. All rights reserved. No reuse allowed without permission.
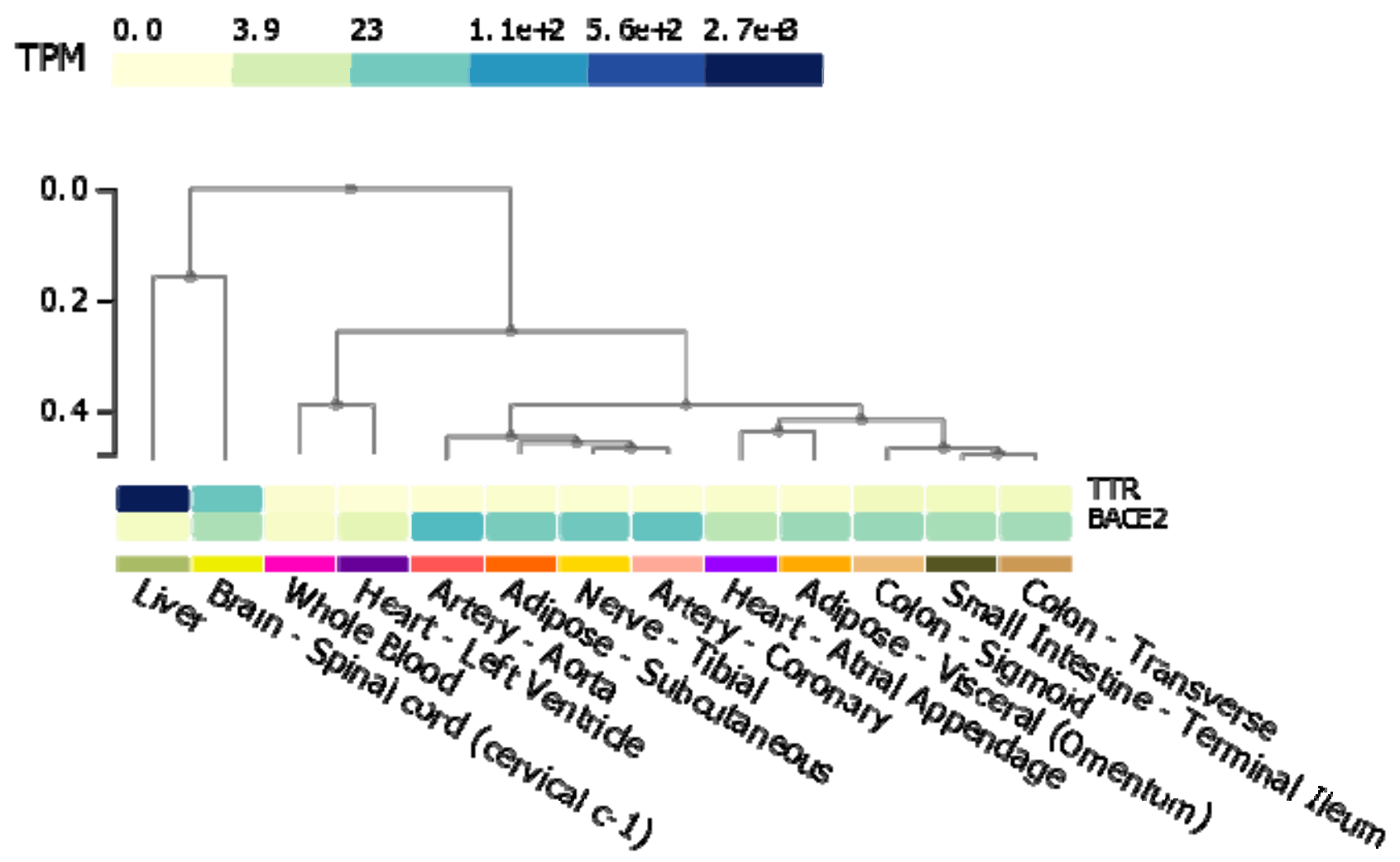

Figure 2: Co-expression of TTR and BACE2 in liver and in hATTR target organs (transcriptomic data from GTEx project, available at https://www.gtexportal.org/). 


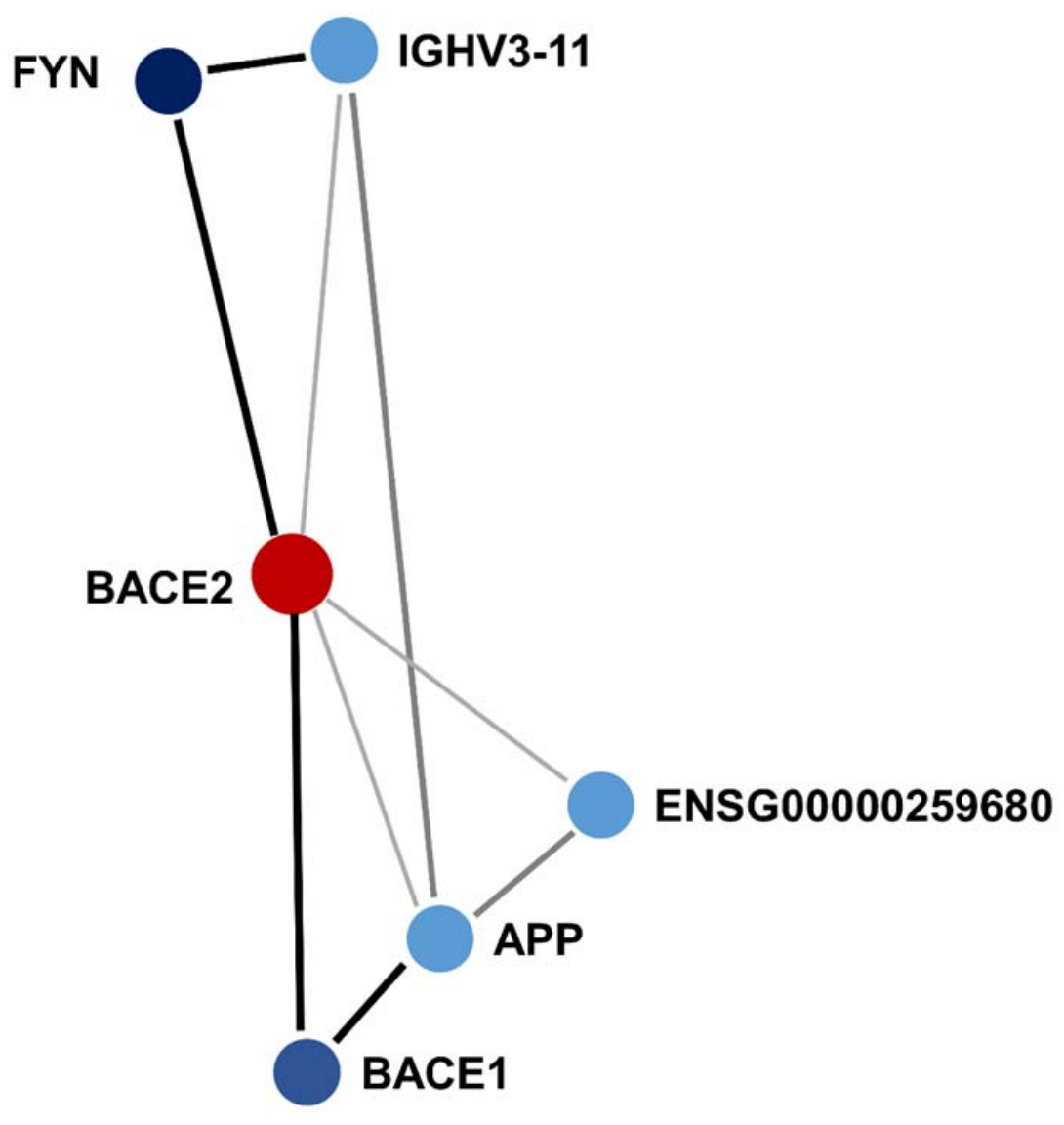

Figure 3. BACE2 protein interaction network. Node colour of the protein is proportional to the interaction score with BACE2. Connector shade and width are proportional to the interaction confidence, highest, high, and medium. 
ID

hsa05010

HSA-2029481

HSA-2730905

HSA-983695

GO:0006509

GO:0050435

GO:1902950

HSA-977225

GO:1904645

HSA-109582

GO:0106027

GO:1900449

HSA-202733

GO:0061098

GO:1903201

GO:0006897

GO:0007631

GO:0016358

GO:0038096

GO:1901216

GO:1903426

GO:1900180

GO:0007612

GO:0031347

GO:2001056

GO:0030162

GO:0051897

\section{Description}

Alzheimer's disease

FCGR activation

Role of LAT2/NTAL/LAB on calcium mobilization

Antigen activates B Cell Receptor (BCR) leading to generation of second messengers membrane protein ectodomain proteolysis amyloid-beta metabolic process

regulation of dendritic spine maintenance Amyloid fiber formation response to amyloid-beta

$$
\text { Hemostasis }
$$

neuron projection organization

regulation of glutamate receptor signaling pathway

Cell surface interactions at the vascular wall

positive regulation of protein tyrosine kinase activity

regulation of oxidative stress-induced cell death

$$
\text { Endocytosis }
$$

feeding behavior

dendrite development

Fc-gamma receptor signaling pathway involved in phagocytosis positive regulation of neuron death

regulation of reactive oxygen species biosynthetic process

regulation of protein localization to nucleus

$$
\text { regulation of defense response }
$$

positive regulation of cysteine-type endopeptidase activity

regulation of proteolysis

positive regulation of protein kinase $\mathrm{B}$ signaling
Proteins

APP,BACE1,BACE2

FYN,IGHV3-11

FYN,IGHV3-11

FYN,IGHV3-11

BACE1,BACE2

BACE1,BACE2

APP,FYN

APP,BACE1

APP,FYN

APP,FYN,IGHV3-11

APP,FYN

APP,FYN

FYN,IGHV3-11

APP,FYN

APP,FYN

APP,FYN,IGHV3-11

APP,FYN

APP,FYN

FYN,IGHV3-11

APP,FYN

APP,FYN

APP,FYN

APP,FYN

APP,FYN,IGHV3-11

APP,FYN

APP,FYN,IGHV3-11

APP,FYN
False Discovery Rate

2.2E-04

$7.9 \mathrm{E}-04$

7.9E-04

0.002

0.007

0.007

0.007

0.008

0.009

0.010

0.010

0.010

0.010

0.017

0.017

0.018

0.018

0.018

0.018

0.018

0.018

0.020

0.027

0.027

0.027

0.031

0.031 


\begin{tabular}{|c|c|c|c|}
\hline GO:2000377 & regulation of reactive oxygen species metabolic process & APP,FYN \\
\hline HSA-168249 & Innate Immune System & APP,FYN,IGHV3-11 \\
\hline HSA-76002 & Platelet activation, signaling and aggregation & APP,FYN \\
\hline GO:0050808 & synapse organization & APP,FYN \\
\hline GO:1901215 & negative regulation of neuron death & APP,FYN \\
\hline GO:0002684 & positive regulation of immune system process & 0.032 \\
\hline GO:0050776 & regulation of immune response & APP,FYN,IGHV3-11 \\
\hline GO:0002252 & immune effector process & APP,FYN,IGHV3-11 \\
\hline GO:0007411 & axon guidance & 0.034 \\
\hline GO:0019538 & protein metabolic process & 0.037 \\
\hline GO:0006959 & humoral immune response & 0.041 \\
\hline
\end{tabular}


17 Table 2: Description of the study population. Information about TTR amyloidogenic mutations, sex, age, epigenetically-determined smoking status (never 18 smoker, NS; former smoker, FS; current smoker, CS), and epigenetically-estimated ranges of T cells (CD8T and CD4T), Natural Killer cells (NK), B cells, 19 monocytes (Mono) and granulocytes (Gran) are reported.

20

\begin{tabular}{|c|c|c|c|c|c|c|c|c|c|c|c|c|}
\hline \multirow{2}{*}{$\begin{array}{c}\text { TTR } \\
\text { Mutation }\end{array}$} & \multirow{2}{*}{$N$} & \multirow{2}{*}{$\begin{array}{c}\text { Sex } \\
\text { Female }(\%)\end{array}$} & \multirow{2}{*}{$\begin{array}{c}\text { Age Median } \\
(\text { Min-Max) }\end{array}$} & \multicolumn{3}{|c|}{ Smoking } & \multirow{2}{*}{$\begin{array}{l}\text { CD8T Median } \\
(\text { Min-Max })\end{array}$} & \multirow{2}{*}{$\begin{array}{l}\text { CD4T Median } \\
(\text { Min-Max })\end{array}$} & \multirow{2}{*}{$\begin{array}{l}\text { NK Median } \\
(\text { Min-Max) }\end{array}$} & \multirow{2}{*}{$\begin{array}{l}\text { B cell Median } \\
(\text { Min-Max })\end{array}$} & \multirow{2}{*}{$\begin{array}{l}\text { Mono Median } \\
(\text { Min-Max })\end{array}$} & \multirow{2}{*}{$\begin{array}{r}\text { Gran Median } \\
(\text { Min }- \text { Max })_{\overparen{c}}\end{array}$} \\
\hline & & & & $N S$ & $F S$ & $C S$ & & & & & & \\
\hline \multicolumn{13}{|c|}{ Cases } \\
\hline Val30Met & 33 & $10(30)$ & $\begin{array}{c}65 \\
(31-88)\end{array}$ & 1 & 23 & 9 & $\begin{array}{c}0.033 \\
\left(-3.24 \times 10^{-20}-0.131\right)\end{array}$ & $\begin{array}{c}0.118 \\
\left(1.1 \times 10^{-2}-0.21\right)\end{array}$ & $\begin{array}{c}0.033 \\
\left(-3.81 \times 10^{-19}-0.127\right)\end{array}$ & $\begin{array}{c}1.52 \times 10^{-3} \\
\left(-5.55 \times 10^{-19}-0.066\right)\end{array}$ & $\begin{array}{c}0.082 \\
(0.038-0.147)\end{array}$ & $\begin{array}{c}0.634 \\
(0.551-0.82\end{array}$ \\
\hline Phe64Leu & 8 & $1(12)$ & $\begin{array}{c}70 \\
(48-75)\end{array}$ & 0 & 4 & 4 & $\begin{array}{c}4.02 \times 10^{-3} \\
\left(1.07 \times 10^{-18}-1.112\right)\end{array}$ & $\begin{array}{c}0.127 \\
\left(6.9 \times 10^{-2}-0.228\right)\end{array}$ & $\begin{array}{c}0.014 \\
\left(1.96 \times 10^{-20}-0.099\right)\end{array}$ & $\begin{array}{c}3.13 \times 10^{-3} \\
\left(-2.17 \times 10^{-19}-0.021\right)\end{array}$ & $\begin{array}{c}0.085 \\
(0.057-0.107)\end{array}$ & $\begin{array}{c}0.65 \\
(0.46-0.70)\end{array}$ \\
\hline Ala120Ser & 2 & $2(100)$ & $67-68$ & 0 & 2 & 0 & $-3.34 \times 10^{-20}-0$ & $0.068-0.11$ & $8.1 \times 10^{-3}-1.28 \times 10^{-1}$ & $0-5.1 \times 10^{-3}$ & $0.092-0.11$ & $0.56-0.7$ 象 \\
\hline Ile68Leu & 3 & 0 & $\begin{array}{c}53 \\
(30-62)\end{array}$ & 0 & 0 & 3 & 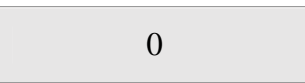 & $\begin{array}{c}0.142 \\
(0.07-0.16)\end{array}$ & $\begin{array}{c}0.038 \\
(0.013-0.041)\end{array}$ & $\begin{array}{c}4.4 \times 10^{-3} \\
\left(3.8 \times 10^{-3}-5.1 \times 10^{-3}\right)\end{array}$ & $\begin{array}{c}0.083 \\
(0.096-0.147)\end{array}$ & $\begin{array}{r}0.59 \\
(0.603-0.7\end{array}$ \\
\hline Val122Ile & 1 & 0 & 80 & 0 & 0 & 1 & 0 & 0.23 & 0.042 & 0.005 & 0.071 & 0.55 \\
\hline rs36204272* & 1 & 0 & 65 & 0 & 1 & 0 & 0.069 & 0.14 & 0.052 & 0.006 & 0.129 & 0.505 \\
\hline \multicolumn{13}{|c|}{ Controls } \\
\hline- & 32 & $19(59)$ & $37(20-76)$ & 0 & 27 & 5 & $\begin{array}{c}0.015 \\
\left(8.45 \times 10^{-19}-0.13\right)\end{array}$ & $\begin{array}{c}0.16 \\
(0.045-0.34)\end{array}$ & $\begin{array}{c}0.044 \\
\left(-2.68 \times 10^{-19}-0.18\right)\end{array}$ & $\begin{array}{c}0.014 \\
\left(1.08 \times 10^{-19}-0.091\right)\end{array}$ & $\begin{array}{c}0.092 \\
(0.051-0.13)\end{array}$ & $\begin{array}{r}0.571 \\
(0.41-0.78\end{array}$ \\
\hline
\end{tabular}

21 *non-coding variant with putative clinical impact 